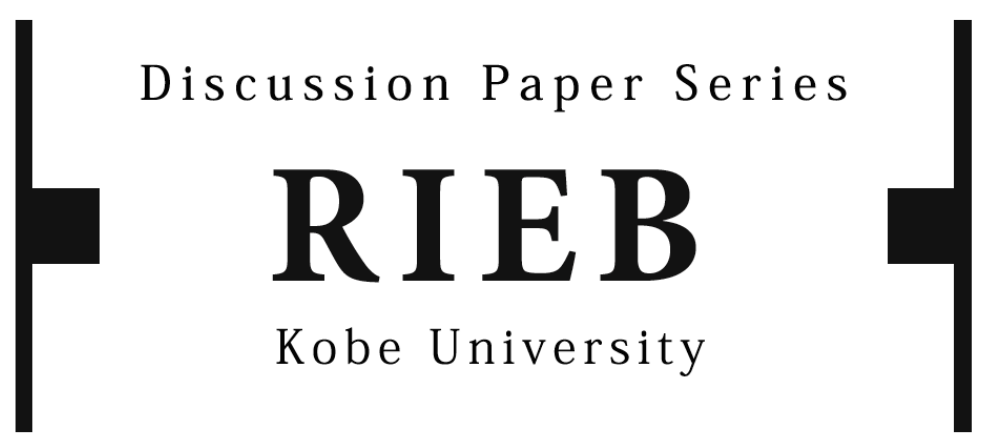

DP2021-01

How Political Conflicts Distort

Bilateral Trade: Firm-Level

Evidence from China*

\author{
Yuhua LI \\ Ze JIAN \\ Wei TIAN \\ Laixun ZHAO \\ January 6, 2021
}

* The Discussion Papers are a series of research papers in their draft form, circulated to encourage discussion and comment. Citation and use of such a paper should take account of its provisional character. In some cases, a written consent of the author may be required.

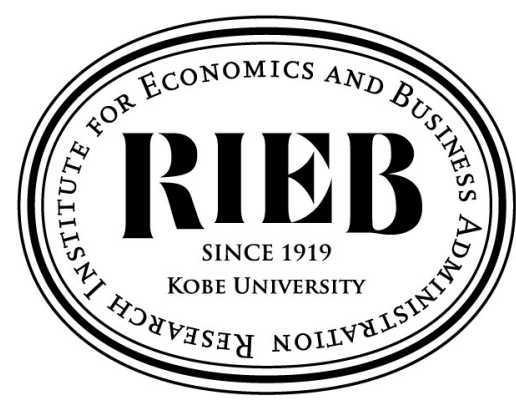

Research Institute for Economics and Business Administration

Kobe University

2-1 Rokkodai, Nada, Kobe 657-8501 JAPAN 


\title{
How Political Conflicts Distort Bilateral Trade: Firm-Level Evidence from China*
}

\author{
Yuhua $\mathrm{Li}^{\dagger} \quad$ Ze Jian$\quad$ Wei Tian` ${ }^{\ddagger} \quad$ Laixun Zhao
}

December 31, 2020

\begin{abstract}
We examine how political conflicts affect trade, using both the Goldstein score that scales all political conflicts daily worldwide and the firm-country-product level data of Chinese imports. We find that political conflicts reduce Chinese imports in general. Specifically, (i) the imports of State-owned enterprises (SOEs) are most reduced, and the effects mostly fall on imports for intermediate goods while not so much on capital goods; (ii) foreign-invested enterprises (FIEs) are less negatively affected, because most of their trade is processing, which is less negatively affected by political conflict than ordinary trade. These results are obtained via mechanisms in the mode of trade (processing vs. ordinary), variations in broad economic categories (BEC) and import boycotts and export controls.
\end{abstract}

JEL: F1, F51

Keywords: Political conflicts; trade; State-owned enterprises; Goldstein score

\footnotetext{
${ }^{*}$ The paper has been financially supported by the Natural Science Foundation of China (\#71363016, \#71503110, \#71672051, \#71863010, \#71972063 and \#72073005), JSPS grants (\#16H02016, \#18H00851, \#19H00594 and \#19H01484) and Shanghai Institute of International Finance \& Economics. We are extremely grateful to two anonymous referees, Mi Dai, Suqin Ge, Jiandong Ju, Seung Hoon Lee, Zhiyuan Li, Nori Nakanishi, Larry Qiu, Sudipta Sarangi, Bin Sheng, Jianwei Xu, Xiaopeng Yin, Eden Yu, Miaojie $\mathrm{Yu}$, Yifan Zhang, Hongjun Zhao, Zhong Zhao, Lianming Zhu and participants at the JEBO conference in May 2019, PKU, for their insightful comments and suggestions. Any remaining errors are our own.

${ }^{\dagger}$ Zhejiang University of Finance \& Economics

${ }^{\ddagger}$ Guangdong University of Finance \& Economics

${ }^{\S}$ School of Economics, Peking University

ॠCorresponding author: Laixun Zhao, Research Institute for Economics \& Business, Kobe University, Kobe 657-8501, Japan; zhao@rieb.kobe-u.ac.jp.
} 


\section{Introduction}

Political conflicts are the series of conflict events initiated by one country (usually government) towards another which can destroy the stability of political relationships ${ }^{1}$. Conflicts may lead to serious consequences in international trade and cooperation in various ways such as raising trade and production cost, increasing trade uncertainty and generating trade diversion. In this paper, we investigate the effects of political conflicts on Chinese imports from its trading partners, particularly focusing on the heterogeneous impacts across firm ownership, trade modes and product categories. We attempt to uncover the possible mechanisms behind from the perspectives of import boycotts and export controls, by using both the Goldstein score data and customs trade data. The Goldstein data records all political conflicts daily on a global scale including those initiated by either China or its trading partners. The trade dataset, compiled at highly disaggregated firm-product-country level, could help mitigate the potential reversal effect of trade on political conflicts, and convey comprehensive information from multiple dimensions.

We find that political conflicts reduce Chinese imports in general. Specifically, Stateowned enterprises (SOEs) are more negatively affected than non-SOEs, consistent with Du et al. (2017) and Davis et al. (2019), and we further show that the effects are reflected more in intermediate goods rather than capital goods. The rationale is, SOEs and capital goods are more likely to be harmed by foreign sanctions because capital goods imports are necessary for the construction and maintenance of lifeline industries such as railways, highways, airlines, oil, and gas in which SOEs are dominant. This dominance hurts SOEs because the imported capital goods are difficult to be substituted, due to a lack of technology to produce them domestically. Also, on the side of importers, SOEs are more subjective to the political duty of boycotts in response to conflicts, since the top managers of SOEs are usually appointed by the government. These together could well explain the significant reduction of imports on intermediate goods rather than capital

\footnotetext{
${ }^{1}$ Kastner (2007) defines an international political conflict as the extent to which the political goals or interests of two countries diverge.
} 
goods. Moreover, we find that compared with domestic private invested enterprises (PIEs) and SOEs, the imports of foreign-invested enterprises (FIEs) are less negatively affected by political conflicts, because most FIEs conduct processing trade, which is embedded in the global value chain. Finally, we find that the impacts of political conflicts vary across different trading partners.

To deal with the endogeneity that might arise from measurement errors, omitted variables or reverse causality, we make a number of efforts. First we use micro based, firmcountry-product-year level observations which mitigates the reverse causality of trade on aggregate national level political conflicts; second we exclude trade-, business- and economic-related conflict events from our political conflicts data; third we conduct instrumental variable (IV) tests and use multiple fixed effects to control for the idiosyncratic shocks, and finally we also test the results using different measures of conflicts all of which yield consistent results. These experiments shed light to the mechanisms as to how aggregate conflicts pass on to individual firms, namely, through firm ownership and product categories.

Several studies in the literature are closely related to us. A government may take measures to punish the nations in conflict, using trade sanctions, embargoes, import quotas and foreign exchange regulations (Stein, 2003; Kastner, 2007). National security reasons could lead a country to decrease trade with an adversary for fear that the adversary's real income gains from trade could be put into military uses, or it could fear increased dependence on trade with the adversary (Gowa and Mansfield, 1993). Chavis and Leslie (2009) find that American boycotts decrease the sales of French wine in the U.S. Michaels and Zhi (2010) show that worsening consumer attitudes caused by the deterioration of relations between the U.S. and France reduce French-U.S. bilateral trade by about $9 \%$ during 2002-2003. Finally, pressures from the government and consumers could change a firm's trade decision. For instance, Martin et al. (2008) argue that conflicts increase trade cost by affecting transportation and infrastructure, and Li and Sacko (2002) and Handley and 
Limao (2017) find that policy uncertainty caused by governments and consumer boycotts increase the risk of foreign trade a firm faces.

In contrast, the Chinese economy is markedly different from that of any other developing country in the past. It not only is large in scale, but also keeps different firm ownerships and different modes for trade, based on which the government may even apply different policies. As such, the present paper examines the effects of political conflicts by different ownerships and trade modes. Heilman (2106) highlights the impact of import boycotts, and Davis et al. (2019) find that SOEs are greatly affected by political conflicts. In contrast, we examine the possible mechanisms from two different perspectives: import boycotts and export controls, and uncover different impacts of political conflicts in intermediate, capital and consumer goods, as well as in trade modes.

Elsewhere, the relationship between political conflicts and international trade has also attracted substantial interest (Berger et al., 2013). Most of the literature focuses on the effects of specific political events, such as, the Japanese invasion of China before World War II (Che et al., 2015), the Dalai Lama visits (Fuch and Klann, 2013), the Diaoyu/Senkaku Island disputes in 2012 between China and Japan (Heilmann, 2016), the Gaza conflict in 2014 between Turkey and Israel (Heilmann, 2016), and the relationship between China and several major powers (Du et al., 2017) ${ }^{2}$.

While the study of specific events is important, the conclusions from specific events can be biased. Table A3 in the Appendix lists the severest conflict events (Goldstein score $<=-9$ ) between China and other trading partners during 2000-2006. Many countries are on the list, such as the Kyrgyz Republic, the United States, the Great Britain, Syria, Pakistan, Norway, Afghanistan, and Iraq. Yet, a typical Chinese national would think that Japan is the No. 1 enemy at all times, even though there are no -10 scores with

\footnotetext{
${ }^{2}$ More specifically, Fuch and Klann (2013) find countries that receive the Dalai Lama experience a significant reduction in exports to China. Che et al. (2015) find a long-term impact of the 2nd SinoJapanese war on cross-border trade and investment. By examining four incidents of politically motivated boycotts, Heilmann (2016) shows an aggravating effect of conflict on trade through boycotts in consumer goods. Du et al. (2017) examine the political relations between China and several major powers and find a temporal aggregation effect of worsening political relations on trade.
} 
Japan in this period. Would Chinese trade be more affected by the biased attitudes of the typical Chinese, or by the standard Goldstein score? Our study in this paper can shed some light.

Also, in reality, major military confrontations are not as common and may not play as big roles as one might think. In the Goldstein score, -10 represents the severest conflict. Yet in reality the media rarely reports and the general public barely notices those -10 events between China and the partner countries (see Table A3). As a matter of fact, in our dataset, major conflict events (with a score lower than -9) initiated by China against other countries are only $4.29 \%$, and the mutually initiated major conflict events are $6.42 \%$ of the total. The majority of political conflicts exhibits in smaller events, such as demanding rights, demanding release of persons, expelling or deporting of individuals, official protest, media protest, halting negotiation, holding demonstration, recalling of diplomats, etc. However, studies on such "lower-level conflicts" have been rare. The main reason lies perhaps in that there are too many lower-level general conflict events, and it is not only hard to get the data but even harder to extract consistent hypothesis on them. Fortunately, with the revolution in information and communications technology, we are able to obtain big data, and especially with several rounds of careful investigations, we believe we have successfully dealt with this big data and numerous events and found coherent explanations.

The rest of the paper is organized as follows. Section 2 documents background studies, Section 3 deals with data treatment, conflict measurement and model specification, Section 4 presents the empirical results, and Section 5 includes conclusions and discussion. Tables, figures and appendexes are delegated to the end of the paper.

\section{Background Studies}

In this short section, we present some basic facts about Chinese firms and imports, which will be useful for subsequent analysis. 


\subsection{Firm ownership in China}

As is well known, there exist three typical firm ownerships in China: SOEs, FIEs and PIEs. SOEs have a close relationship with the government. (i) Each publicly owned firm not only has a CEO as in western firms but also a Secretary of the Communist Party, and the top managers of major SOEs are appointed by the central or provincial government, which are mostly senior members of the Communist Party. In a number of cases, the CEO and Party Secretary are even the same person ${ }^{3}$. They thus have the incentive to serve the demands from the government, especially during political conflicts with foreign countries. (ii) Economically, SOEs have privileged access to more and cheaper capital and other regulatory benefits, including favorable taxation, subsidies, and preferential financing from government or State-owned commercial banks (Dewenter and Malatesta, 2001; Lu et al., 2012). Studies show that over 75 percent of the country's capital, which is largely provided by State-owned banks, flows to SOEs (Cull and Xu, 2003). Therefore, SOEs serve the political mandates of the State and align their interests with particular social, economic, or political objectives deemed necessary for the government (or national) interest. And it is hence understandable that when political conflicts arise, SOEs may follow the government's orders to reduce importing goods from countries in conflict. In contrast, FIEs and PIEs do not have a close relationship as SOEs with the government. With the onset of international conflicts, it would be interesting to see which type of firms follow government orders more closely.

Also, other countries may impose restrictions on exports to Chinese SOEs, an example of which is the Wassenaar Arrangement (WA $)^{4}$, that aims to impose export control on

\footnotetext{
${ }^{3}$ In China, two central organizations - the Central Organization Department (COD), the head of which is a member of the Politburo, and the State-Owned Assets Supervision and Administration Commission (SASAC), with the approval of COD - have the authority to appoint the leadership of the country's 102 remaining centrally-owned SOEs.

${ }^{4}$ The Wassenaar Arrangement (WA) is the arrangement on export controls for conventional arms and dual-use good and technologies., See the official website: https://www.wassenaar.org/. The purpose is to restrict the export of strategic materials and high technology from member countries to socialist countries. Although the WA requires member States to issue export licenses for sensitive products and technologies at their own discretion, and inform other member States of the arrangement of relevant information on a voluntary basis. China, Iran and Libya are all on the list of restricted countries. But the "arrangement" is
} 
strategic materials and high technology from member countries to socialist countries, in particular controls for conventional arms and dual-use good and technologies ${ }^{5}$. Under the Wassenaar Arrangement, SMIC, China's leading semiconductor-chip foundry, cannot buy the most advanced manufacturing equipment. Instead, it buys second-hand equipment from the Interuniversity Microelectronics Centre (IMEC), after 5 years of use at IMEC 6 .

In addition, non-SOE firms may be sanctioned during a political tension, especially in hi-tech. industries. For instance, after the U.S. put Huawei on the "entity list", Chip makers such as Intel, Lumentum, Qualcomm, Xilinx and Broadcom stopped supplying to Huawei ${ }^{7}$.

\subsection{Chinese imports and firm ownership}

In our sample, the shares of import value for SOEs, FIEs, and PIEs are 33.75\%, 56.51\%, and $6.25 \%$ respectively. That is, FIEs are the biggest importer, occupying more than half of total Chinese imports. Table 1 reports Chinese import percentage by category. It imports more intermediate and capital goods than consumption goods. The import value shares of intermediates, capital and consumption goods are $62.64 \%, 19.96 \%$ and $3.36 \%$ respectively. In addition, the import value shares of ordinary and processing products are $44.95 \%$ and $55.05 \%$ respectively. FIEs import more processing products than ordinary products, while SOEs and PIEs do the opposite. Specifically, SOEs import $72.69 \%$ ordinary and $27.31 \%$ processing products, whereas, FIEs import $25.15 \%$ ordinary and $74.85 \%$ processing products.

[Insert Table 1 here: Import value percentage by ownership, category and mode]

in fact completely controlled by the U.S. When a country under the WA intends to export a certain high technology to China, the U.S. often intervenes directly.

${ }^{5}$ Dual-use goods and technologies, covering: advanced materials, material processing, electronic devices, computers, telecommunications and information security, sensors and lasers, navigation and avionics, ships and maritime equipment, etc. There are more than ten thousand products in three categories, including military weapons and equipment, cutting-edge technology products and rare materials. Most of these items are capital goods.

${ }^{6}$ https://tech.qq.com/a/20180419/000258.htm

${ }^{7}$ https://futurumresearch.com/sanctions-against-huawei-impact-us-chipmakers-and-other-tech-cos/ 


\section{Data Treatment, Conflict Measurement and Model Spec- ification}

The trade data are from China Customs database, which covers the transactions of every Chinese trading firm by partner country, with information on trade value, trade quantity (i.e., physical units), 8-digit Harmonized System (HS) industry classification, and ownership type. Since only the data for the period 2000-2006 provides the ownership type information, our study focuses on this period. The GDP, population, and the consumer price index in U.S. dollars (2010 as base year) which is used to deflate trade to get the real trade value (Rose, 2007), are from the World Development Indicators (WDI). The main political conflicts data are from the Global Data on Events, Location and Tone (GDELT), which is the largest online spatial-temporal database covering daily political conflicts and cooperation events recorded by worldwide broadcast, print, and web news and updated daily in over 100 languages from 1979 to the present ${ }^{8}$.

\subsection{Political conflicts}

\subsubsection{Conflict measurement}

The GDELT database has been used to study bilateral international conflicts (Leetaru and Schrodt, 2013; Gleditsch et al., 2014; Davis et al., 2019). It uses the Conflict and Mediation Event Observations (CAMEO) coding scheme, and each CAMEO event code is assigned a numeric Goldstein score from -10 to +10 , capturing the theoretical potential impact of that type event on the stability of a country. Conflict events are measured by negative numbers from -10 to 0 . Appendix A1 lists all the types of conflicts, such as business, government, education, human rights, health, etc. We select the negative events under the category of "government", i.e., events initiated by the government of one country toward another country.

\footnotetext{
${ }^{8}$ The GDELT Event Database records over 300 categories of physical activities around the world, from riots and protests to peace appeals and diplomatic exchanges across the entire planet dating back to January 1, 1979 and updated daily (every 15 minutes). GDELT event records are stored in an expanded version of the dyadic CAMEO format. See http://gdeltproject.org/.
} 
In GDELT's coding scheme, political conflict events usually include: use conventional military force, investigate, arrest and detain, charge with legal action, abductor hijack, take hostage, criticize or denounce, threaten, demonstrate or rally, complain officially, engage in political dissent, accuse, reject, defy norms and law, reduce relations, mobilize or increase armed forces, demonstrate military or police power, boycott, stop aid, sanctions, demand aid, demand cooperation, etc. Appendix A2 lists all the political conflict events in our sample.

We construct a variable Conflict $_{j t}$, as the sum of absolute Goldstein score of the conflict events between China and country $\mathrm{j}$ in year $\mathrm{t}$, and divide it by 1000 to avoid small coefficients. As a preliminary step to avoid endogeneity, we exclude the conflict events related to trade, business and economics (See Table A2 in the Appendix). Appendix A3 lists the largest conflict events (with a score of -9 or lower) between China and other countries.

\subsubsection{Measurement accuracy}

We now explain the accuracy of the constructed variable in general. The political conflicts between China and the U.S., China and Japan are respectively shown in Figure 1, where one sees it captures really well the small as well as big events ${ }^{9}$.

For the conflicts between the U.S. and China, there are three peaks, in 1989, 1999, 2010-2013 respectively. Due to the Tiananmen Square events on June 4, 1989, the U.S. imposed a ban on arms shipments to China and halted high-level official talks ${ }^{10}$. In 1999, U.S. guided bombs hit the Chinese embassy in the Belgrade district of Yugoslavia, killing three Chinese reporters and outraging the Chinese public ${ }^{11}$. The conflicts between China and the U.S. from 2010 to 2013 were primarily caused by a number of events, including

\footnotetext{
${ }^{9}$ We divide the Goldstein score by the world total conflict events number in the year.

${ }^{10}$ Web of history (2009): Congress votes new sanctions against China. http://www.history.com/ this-day-in-history/congress-votes-new-sanctions-against-china, accessed 1 June 2018.

Andrew G. (2011): House Sanctions Post-Tiananmen China, June 29, 1989. https://www.politico.com/ story/2011/06/house-sanctions-post-tiananmen-china-june-29-1989-057928, accessed 1 June 2018.

${ }^{11}$ Wikipedia (1999). United States bombing of the Chinese embassy in Belgrade. https://en.wikipedia. org/wiki/United_States_bombing_of_the_Chinese_embassy_in_Belgrade, accessed 1 June 2018.
} 
the U.S. policy of "rebalancing to Asia"12, the rapid growth of U.S. arms sales to Taiwan, President Obama meeting the Dalai Lama ${ }^{13}$, and network security issues ${ }^{14}$.

For the conflicts initiated by China toward Japan, there are six peaks in 1982, 1985, 1996, 2005-2006, 2010 and 2012 respectively. In 1982, the Japanese government authorized the use of a history textbook that, according to critics, whitewashed Japanese war crimes of World War II. On August 15, 1985, Prime Minister Nakasone and his cabinet officially visited the Yasukuni Shrine, who was the first Japanese prime minister to visit the Shrine as a public officer after World War II. Since then, the Shrine has become an important source of conflict between China and Japan. ${ }^{15}$ In 1996, China conducted two nuclear tests, which Japan protested against. Also, a group of Japan Youth Club members landed on the Diaoyu/Senkaku islands. The conflicts around 2005-2006 were caused both by the official visit of Japanese Prime Minister Koizumi to the Yasukuni Shrine and by the Japanese government's approval of New History Textbooks in April 2005 (Fisman et al., 2014). ${ }^{16}$ The conflicts in 2010 and 2012 arose respectively from the Diaoyu/Senkaku boat collision incident in 2010 and the Japanese nationalization of the Islands in 2012. ${ }^{17}$

[Insert Figure 1 here: Political conflicts: China vs. USA, China vs. Japan]

\subsection{Trade data}

We use the consumer price index in U.S. dollars to deflate trade to get the real trade value (Rose, 2007; Yu, 2015), since the trade data are recorded in current U.S. dollars.

\footnotetext{
${ }^{12}$ https://warontherocks.com/2013/07/rebalancing-toward-asia-and-protecting-u-s-interests-the-devilis-in-the-details/

${ }^{13}$ Since China considers the status of Tibet as an internal affair, the meetings of the Dalai Lama with foreign officials as a leader of the Tibetan community, are seen by China as a threat the integrity of the Chinese nation (Fuchs and Klann, 2013).

${ }^{14}$ Google exited mainland China in 2011 because of network security issues.

${ }^{15}$ http://articles.latimes.com/1985-08-16/news/mn-3020_1_official-visits, accessed 1 June 2018.

${ }^{16}$ A Shinto shrine is dedicated to Japanese war deaths, including Class-A convicted war criminals in WWII.

${ }^{17}$ Wikipedia (2011). The 2010 Senkaku boat collision incident. https://en.wikipedia.org/wiki/2010_Senkaku_boat_collision_incident, accessed 1 June 2018;

CNN (2012):. How a remote rock split China and Japan. http://edition.cnn.com/2012/09/17/ world/asia/china-japan-islands-dispute-explained/index.html, accessed 1 June 2018.
} 
Ln_Import is the natural logarithm of the deflated import value of Chinese firms. Our sample includes 204133 firms' imports from 174 countries covering the period 2000-2006. Table 2 contains the descriptive statistics. SOEs occupy $25.9 \%$ observations; and $44.3 \%$ of the observations is ordinary trade and the rest is processing trade. Also, our regression analyses are based on the Classification by Broad Economic Categories (BEC), which is divided into capital, intermediate, and consumption goods. $69.3 \%$ observations in our sample are in intermediate goods, $20.4 \%$ and $10.1 \%$ are capital and consumption goods respectively.

[Insert Table 2 here: Descriptive statistics]

\subsection{Variables and model specification}

We construct the following model:

$$
\text { Ln_import }_{i j p t}=\alpha+\beta_{1} \text { Conflict }_{j t}+\beta_{2} \text { Conflict }_{j t-1}+\eta X+\gamma_{i t}+\lambda_{j}+\Psi_{p}+\epsilon_{i j p t}
$$

where $L n \_$import $_{i j p t}$ is the natural logarithm of the import value for firm $i$ from country $j$ of product $p$ (HS6 code) in year $t$, Conflict f $_{j t}$ is the the sum of absolute Goldstein score of the conflicts between China and country $j$ in year $t$, and Conflict $_{j t-1}$ is the one-year lagged term. $X$ includes a set of control variables. To control for the impact of industry competition on firms' imports, we add the Herfindahl-Hirschman Index, Imp_HHI $I_{j p t}$, calculated as the sum of the squares of market shares of the importing firms from country $j$ for product $p$ (HS6 code) in year $t$. Exchange $j t$ is the exchange rate of country $j$ 's currency to Chinese $\mathrm{RMB}, L n G D P_{j t}$ is natural logarithm of country $j$ 's GDP, and $\operatorname{LnPOP}_{j t}$ is the natural logarithm of country $j$ 's population, all in year $t$.

In addition, we use the firm level time-varying fixed effect $\gamma_{i t}$ to control for firm characteristics such as productivity, and incorporate country $j$ 's fixed effect $\lambda_{j}$ and product $p$ (HS6)'s fixed effect $\varphi_{p}$. And finally, $\epsilon_{i j p t}$ is the error term. 


\section{Empirical Results}

\subsection{Impacts on Chinese imports}

Table 3 reports the impacts of political conflicts on Chinese imports. Column (1) includes the current Conflict ${ }_{j t}$, to which column (2) adds one-year lagged conflict to consider the time delay of the impact ${ }^{18}$. The estimated coefficients for Con flict $_{j t}$ are negative and significant. These results are consistent with Fuch and Klann (2013), Heilmann (2016) and Du et al. (2017), suggesting that political conflicts reduce trade. However, the magnitude is not large. We find that with all else being equal, one standard deviation rise (0.009) in political conflicts results in 0.74 percent decrease in imports. But for the moment bear in mind that political conflicts rarely rise by a small percentage, rather, tensions could escalate abruptly and significantly, which may lead to large fluctuations in trade.

It might be the case that the results are driven by a particular large country which has both large trade volume and intensive conflicts with China ${ }^{19}$. So column (3) excludes two major countries as possible outliers, the U.S. and Japan. The decline in significance and coefficient size suggests that the two countries are indeed major friction and trading partners, so we deal with endogeneity in Table 10. Columns (4)-(6) take into account possible problems with the composition of political conflict indicators. To take a specific look at the impact of major events, we generate two alternative measures. Conflict $3_{j t}$ is constructed to include only the political events that have a value of less than -3 on the Goldstein score, and similarly, Conflict $5_{j t}$ includes only those with a value of less than -5. In addition, the conflicts initiated by China may be different from those initiated by an exporter. Hence, Conflict_other ${ }_{j t}$ is constructed to include only the conflict events initiated by country $j$ to China in year $t$. Using these conflict variables in robustness checks, our results are still in line with those in column (2).

[Insert Table 3 here: Impact of conflicts on Chinese imports]

\footnotetext{
${ }^{18}$ We have also tried other lags of political conflicts, and our results still hold.

${ }^{19}$ We thank an anonymous referee for this suggestion.
} 


\subsection{Effects by BEC categories}

Two potential perspectives might help to explain the reduction effects of political conflicts on Chinese imports: import boycotts and export controls. Though we are not able to test the two channels strictly, they might be reflected through the impacts of different product categories, given capital goods, high tech products and SOE firms are the major targets of export controls. So based on Table 1, we divide our sample into intermediate, capital and consumer goods. Table 4 reports the impact of conflicts by BEC categories. Columns (1)-(3) show the regression results for intermediate, capital, and consumption goods respectively. Columns (4)-(6) report the results for the sample excluding U.S. and Japan.

The results in column (1) indicate that the impact of political conflicts on imports is mainly reflected in intermediate goods, and the negative impact is still significant after the removal of the U.S. and Japan. There are two potential reasons for this phenomenon: First, while export controls imposed by countries in conflict are generally applied to hightech products such as capital goods, import boycotts are more likely to be applied to consumer goods and intermediate goods (Heilman, 2016). Second, the demand elasticity of capital goods is generally low (Chen et al., 2014), and substitution goods are not easy to find. Many important industries, such as high-speed railways, highways, ports, airlines, and petroleum, etc., depend on imported capital goods such as machines and machine tools. In contrast, the demand elasticity of consumer goods and intermediate goods is high (Chen et al., 2014), and hence are easy to be boycotted and substituted. The insignificant coefficients for consumer goods may be due to the fact that compared to the intermediate goods whose purchasers are firms, it is the consumers, rather than firms, who initiate the boycott on consumer goods. And consumers are usually less politically constrained and less sensitive to minor events which are the main composition of the data. Thus boycotts on consumer goods usually occur under limited extent and for shorter durations, leading to an insignificant impact. These results suggest that in general, the impact of political 
conflicts on imports is more likely to be caused by import boycotts rather than export controls.

[Insert Table 4 here: Impact of political conflicts by BEC categories]

\subsection{Effects by ownership}

In order to further investigate the reasons for the decrease in imports of intermediate goods, we take the angle of firm ownership. On the exporters' side, export controls are more likely to be used to target SOEs, however on the importers' side, SOEs on the one hand have the political responsibility to boycott imports when facing political conflicts, one the other hand, they must undertake production activities for the development of lifeline industries, forcing them to increase imports instead, especially in capital goods.

Table 5 reports the impacts of political conflicts by different ownerships. In the first two columns, we find that SOEs are more vulnerable to political conflicts than PIEs and FIEs, and the difference between FIEs and PIEs is not significant. Columns (3)-(4) exclude two possible outliers the U.S. and Japan respectively, considering the fact that the U.S. has more export controls on China and China has more boycotts on imports from Japan. In all columns, the coefficients for the interaction term between FIE and Conflict are not significant. SOEs' imports fall more than those of the other two groups, suggesting they might be more vulnerable to export control restrictions, and they assume the political task of undertaking stronger import boycotts. Combined with Table 4, it seems the latter reason is more likely.

[Insert Table 5 here: Impact of political conflicts by different ownerships]

Next, onto the BEC categories of all SOEs. In Table 6, column (1) shows that SOEs' imports are negatively affected by political conflicts. Further, columns (2)-(4) find that intermediate goods are the most affected, consistent with Table 5. These results indicate 
that on the one hand, SOEs are charged with the political task of import boycotts, and on the other hand, while there may be more restrictions placed on SOEs by exporting countries, there has not been a significant decline in the imports of capital goods, because SOEs are also responsible for the construction and maintenance of the lifeline industries, and thus the import boycotts are mainly reflected in intermediate goods rather than capital goods.

[Insert Table 6 here: Impact of political conflicts for SOEs]

Finally, we deal with the issue of zero trade that may be caused by political conflicts in certain products. Although our dependent variable is in the firm-product-country level where zero trade is usually not a major concern, we aggregate our sample to countryproduct (HS6)-year level, and employ Poisson Pseudo Maximum Likelihood (PPML) to exclude the possible bias generated from missing trade at an aggregated product level. Table 7 reports the results, and they show that after handling zero samples, conflict still has a significant and negative impact on Chinese imports, with SOEs being the most negatively affected, and FIEs the least affected among the three ownership types.

[Insert Table 7 here: Impact of political conflicts (industry-level) by using PPML]

\subsection{Effects on ordinary and processing trade}

Tables 5 and 6 suggest the imports of FIEs and PIEs are least negatively affected by political conflicts, especially FIEs. It might be attributed to the fact that many FIEs are processing trade firms or export firms, which import inputs and export final products, and processing trade accounts for a large share in China's total trade for a long period $(\mathrm{Yu}, 2015)$. On the one hand, these products are sold in overseas markets rather than in domestic markets, so the impact of boycotts in the Chinese domestic markets is relatively small. On the other hand, processing trade firms are more deeply embedded in global 
value chains, where the supply chain of intermediate goods is more stable and less affected by export controls imposed by countries in conflicts than ordinary trading firms (Dai et al., 2016). To this end, we classify our sample into processing trade and ordinary trade. As shown in Table 8, we find that ordinary imports are negative and significantly affected by political conflicts, while processing imports are not significantly affected, consistent with our conjecture.

[Insert Table 8 here: Impact of conflicts on ordinary and processing trade]

\subsection{Effects by country}

Next, we disaggregate the exporter countries into democratic and non-democratic countries. The democracy data are from Polity IV, which has been extensively used to measure world democratization. ${ }^{20}$ The polity scheme records changes in the institutionalized qualities of the governing authority, and measures the qualities of executive recruitment and constraints on executive authority. The polity score provided by the dataset captures political regime authority spectrum on a 21-point scale ranging from -10 (hereditary monarchy) to +10 (consolidated democracy). A negative polity score is treated as non-democracy, and a positive one as democracy.

Table 9 presents the regression results. The estimated coefficients for Conflict from democracy countries in column (1) are negative and significant, whereas the estimated coefficient Conflict in column (3) is insignificant. Columns (2) and (4) incorporate the interaction terms with firm ownership, supporting that compared with other types of firms, SOEs suffer more from the conflicts with democracy trading partners while little from the non-democracy countries. These suggest that conflicts reduce Chinese imports from democracy rather than non-democracy countries. The reason might lie in that, most of China's important trading partners and providers of key intermediate goods and capital goods are democracy countries, who may discriminate against China in export and import choices in times of political conflicts (Gawarkiewicz and Tang, 2017).

\footnotetext{
${ }^{20}$ For example, Yu (2010) and Peterson (2011).
} 
[Insert Table 9 here: Effects of conflicts by different countries]

\subsection{Endogeneity Issues}

The potential endogeneity issues in this paper stem primarily from three sources: measurement errors, omitted variable bias and reverse causality. We make several attempts to mitigate these concerns. First, to control for the measurement error, we take several robust conflict variables as our independent variables, and as shown in Tables 3, our results still hold.

Second, our data structure implies that reverse causality is not very serious in the paper, since it is difficult for an individual firm to influence the aggregate-level political conflicts between two nations, and thus, to a typical firm, international political conflicts in the country-level are obviously exogenous. In addition, we have already excluded trade-, business- and economic-related conflict events from our political conflicts.

Third, we use multiple fixed effects to mitigate concerns about the omitted variable bias. Specifically, the firm-year fixed effects capture a set of time-varying firm characteristics, such as, ownership type, firm size, firm profit, etc. Country fixed effects capture the dyadic country characteristics between country $j$ and China, such as, geographic distance, contiguity, and common language, etc. Product fixed effects capture the product characteristics in HS6 code. These fixed effects to some extent mitigate the bias from omitted variables.

Fourth, in addition to the above steps, we conduct a Two-Stage-Least-Squares (2SLS) analysis. To this end, we construct an IV that influences political conflicts but not trade and error terms. Our IV has two components. (1). The density of military forces that affect the probability of political conflicts between dyadic countries (Dorussen and Ward, 2010). Large countries may have more trade and military personnel at the same time. So we divide military personnel by total population to eliminate the impact of country size. Specifically, density of military personnel (density_personnel) is constructed as the 
ratio of military personnel divided by the total population of country $j$ in year $t$. The military personnel data of each country come from the Correlates of War database ${ }^{21}$. The countries with the highest scores are Democratic People's Republic of Korea, Eritrea, Israel, Lebanon, Jordan, Bahrain, Syria, Oman, Qatar, Hrvatska, all of which are small countries having little trade with China; the scores for China's main trading partners are USA $0.49 \%$, FRA $0.44 \%$, GBR $0.35 \%$, and JPN $0.19 \%$, which are all not among the top score countries. This suggests that the military density is not significantly directly correlated with country size or trade volume with China, and can serve as an exogenous instrumental variable.

(2). A historical decision of establishing diplomatic relations likely affects the political conflicts or cooperation later on, but it may not directly affect a firm's current trade decision through other channels beyond political relations (Li et al., 2018). Thus, Rec_Diplomat_years $j$ is constructed as the reciprocal of natural log of the number of years that China's diplomatic relations have been established with country $j$ in year $t .^{22}$ The diplomatic relations data come from the website of the Ministry of Foreign Affairs of China.

Our IV is constructed as the density of military personnel (density_personel) multiplied by the reciprocal of the natural log of the number of years of established diplomatic relations (Rec_Diplomat_years). We report the first stage regressions in Appendix Table A4, where the instrument variables are significantly positively correlated with the conflict measure. The 2SLS regression results are shown in Table 10. The Anderson-Rubin test F statistics for columns (1) and (2) are 70.85 and 69.99 respectively, rejecting the null hypothesis and implying our IV explains the political conflicts. Note that the correlation between the IV and the error term in the benchmark regression is 0.0002 , suggesting the IV has little impact on imports through the channels other than conflicts. Above all, these results indicate the exogeneity and relevance of our constructed IV and justify its use as

\footnotetext{
${ }^{21}$ The official website of the database: https://correlatesofwar.org/

${ }^{22}$ The data is from the website of China Ministry of Foreign Affairs.
} 
an instrumental variable. These 2SLS regression results are consistent with our previous results.

[Insert Table 10 here: Instrumental variable test]

\section{Conclusions and Discussion}

While most existing economic literature focuses on the effects of specific international conflict events, few of them examine how political conflicts affect international trade in general. Moreover, there is a complete lack of study on the different responses of heterogeneous firm ownership to political conflicts. In this paper, by testing firm-country-product (HS6) yearly trade data, we have examined how the effects of political conflicts on trade change with firms' ownership type and product categories. Our study includes not only big and symbolic events like in the existing literature, but also more general political conflicts with big data, leading to more general and robust conclusions.

Our main findings in the paper can be summarized as follows.

First, the impact of political conflicts on trade may come from two sources: consumer boycotts in the importing countries and export controls in the exporting countries, in particular, export control for SOEs and high-tech products. ${ }^{23}$ We find that the negative impact of political conflicts on intermediate goods importing is greater than capital goods, because capital goods, with a lower elasticity of substitution (Chen et al., 2014), usually bear intensive technology and could not be easily replaced as conflicts occur, particularly in high-tech industries and for SOEs undertaking the development of lifeline industries. This makes capital goods hard to be boycotted by importing firms while easy to be targeted by exporters. And intermediate goods may serve as a better measure to boycott since it is more subjective to production changes and are more easily replaced.

Second, we find different responses from heterogeneous firm ownerships to political conflicts. Compared with FIEs and PIEs, SOEs are more negatively affected by political

\footnotetext{
${ }^{23}$ The Wassenaar Arrangement is a typical form of export control.
} 
conflicts. Two potential reasons may explain the results: first, the SOEs assume a greater role in import boycotts than other type of firms (Du et al.,2017; Davis et al., 2019), reflecting the fact that the intermediates goods importing of SOEs is negatively affected by political conflicts; second, SOEs may be restricted by export control policies of countries in conflict, like the Wassenaar Arrangement often used by the U.S. to restrict the exports of high-tech products to China. The capital goods importing of SOEs has not been seriously affected, suggesting the second channel is weak.

Third, compared with SOEs and PIEs, FIEs are less affected by political conflicts. The possible reasons lie in that many FIEs are processing trade firms. We find that ordinary trade is affected by political conflicts more easily than processing trade because the final products of FIEs are mostly exported abroad, confronting less pressure of domestic boycotts, and the processing trade firms are more deeply embedded in the global value chain, hence are also less exposed to export controls.

We also find that conflicts reduce importing from democracy countries rather than non-democracies, suggesting that differences in political ideology between China and the exporters would affect trade decisions during conflicts.

The paper enriches the literature by discussing the heterogeneous impacts of political conflicts on trade across different product categories and firm ownerships. In the literature, though SOEs are found to be hampered by conflicts more seriously in some studies, the mechanism is still ambiguous. In the present paper, we have provided an insight to uncover the channels from both import boycotts and export controls through careful investigations of different product types, trade modes and ownerships. The paper sheds lights on the linkage between the impact of conflict and global value chain, as emphasized in Antràs and Gortari (2020) that trade cost transfers to firms differently according to the product location in the production chain. Still, future studies may reveal more detailed and direct evidence on the channels.

The impacts of conflicts on Chinese exports are also worth exploring, since it is uncer- 
tain whether there is similar political task of export controls for SOEs or import boycotts of products made by SOEs from the trading partners. Policies such as export tax refund make the investigations more complicated but also more interesting. These interesting issues remain avenues for further research. ${ }^{24}$

\section{References}

[1] Antràs, Pol, and Alonso de Gortari. 2020. "On the Geography of Global Value Chains." Econometrica 84, 4, 1553-1598.

[2] Berger, D., Easterly, W., Nunn, N., Satyanath, S., 2013. Commercial imperialism? Political influence and trade during the Cold War. American Economic Review 103 (2), 863-896.

[3] Burnside, C., Dollar, D., 2000. Aid, policies, and growth. American Economic Review 90 (4), 847-868.

[4] Chavis L., Leslie P., 2009. Consumer boycotts: The impact of the Iraq war on French wine sales in the U.S. Quantitative Marketing and Economics 7 (1), 37-67.

[5] Che, Y., Du, J., Lu, Y., Tao, Z., 2015. Once an enemy, forever an enemy? The long-run impact of the Japanese invasion of China from 1937 to 1945 on trade and investment. Journal of International Economics 96 (1), 182-198.

[6] Chen Y., Chen, X., Cao, L., Li, B. 2014. Estimation of the demand elasticity of China's import. The Journal of World Economy (2), 29-49. (In Chinese)

[7] Cull, R., Xu, L., 2003. Who gets credit? The behavior of bureaucrats and state banks in allocating credit to Chinese state-owned enterprises. Journal of Development Economics 71 (2), 533-559.

[8] Dai, M., Maitra, M., Yu, M., 2016. Unexceptional exporter performance in China? The role of processing trade. Journal of Development Economics 121 (3), 177-189.

[9] Davis, C., Fuchs, A., Johnson, K., 2019. State control and the effects of foreign relations on bilateral trade. Journal of Conflict Resolution 63 (2), 405-438.

\footnotetext{
${ }^{24}$ We thank the referee for the suggestion.
} 
[10] Dorussen, H., Ward, H., 2010. Trade networks and the Kantian peace. Journal of Peace Research 47 (1), 29-42.

[11] Dewenter, K.L., Malatesta, P. H., 2001. State-owned and privately owned firms: An empirical analysis of profitability, leverage, and labor intensity. American Economic Review 91 (1), 320-334.

[12] Du, J., Wang, Y., 2013. Reforming SOEs under China's state capitalism, In: Unfinished Reforms in the Chinese Economy, Edited by Zhang, J., New Jersey: World Scientific Publishing. pp. 1-38.

[13] Du, Y., Ju, J., Ramirez, C.D., Yao, X., 2017. Bilateral trade and shocks in political relations: Evidence from China and some of its major trading partners, 1990-2013. Journal of International Economics 108, 211-225.

[14] Fan, G., Hope, N.C., 2013. The role of state-owned enterprises in the Chinese economy. US-China 2022: Economic Relations in the Next 10 Years, 355-375. https://www.chinausfocus.com/2022/wp-content/uploads/Part+02Chapter+16.pdf, accessed on December 152019.

[15] Fisman, R., Hamao, Y., Wang, Y., 2014. Nationalism and economic exchange: Evidence from shocks to Sino-Japanese relations. Review of Financial Studies 27 (9), 2626-2660.

[16] Fuchs, A., Klann, N., 2013. Paying a visit: The Dalai Lama effect on international trade. Journal of International Economics 91 (1), 164-177.

[17] Gleditsch, K.S., Metternich, N.W., Ruggeri, A., 2014. Data and progress in peace and conflict research. Journal of Peace Research 51 (2), 301-14.

[18] Gowa, J., Mansfield, E.D., 1993. Power politics and international trade. American Political Science Review 87 (2), 408-420.

[19] Handley, K., Limao, N., 2017. Policy uncertainty, trade and welfare: Theory and evidence for China and the U.S. American Economic Review 107 (9), 2731-2783.

[20] Heilmann, K., 2016. Does political conflict hurt trade? Evidence from consumer boycotts. Journal of International Economics 99, 179-191. 
[21] Kastner, S.L., 2007. When do conflicting political relations affect international trade? Journal of Conflict Resolution 51 (4), 664-688.

[22] Leetaru, K., Schrodt, P., 2013. GDELT: Global data on events, language, and tone, 1979-2012. In International Studies Association Annual Conference, April 2013, San Diego, CA.

[23] Li, J., Meyer, K.E., Zhang, H., Ding, Y., 2018. Diplomatic and corporate networks: Bridges to foreign locations. Journal of International Business Studies 49 (6), 659-683.

[24] Li, Q., Sacko, D.H., 2002. The (ir) relevance of militarized interstate disputes for international trade. International Studies Quarterly 46 (1), 11-43.

[25] Lu, Z., Zhu, J., Zhang, W., 2012. Bank discrimination, holding bank ownership, and economic consequences: Evidence from China. Journal of Banking \& Finance 36 (2), $341-354$.

[26] Martin, P., Mayer, T., Thoenig, M., 2008. Make trade not war? Review of Economic Studies 75 (3), 865-900.

[27] Michaels, G., Zhi, X., 2010. Freedom fries. American Economic Journal: Applied Economics 2 (3), 256-281.

[28] Peterson, T.M., 2011. Third-party trade, political similarity, and dyadic conflict. Journal of Peace Research 48(2), 185-200.

[29] Rose, A.K., 2007. Do we really know that the WTO increases trade? American Economic Review 97 (5), 2019-2025.

[30] Russett, B., Oneal, J.R., 2001. Triangulating peace: democracy interdependence and international organizations. New York: Norton.

[31] Stein, A.A., 2003. Trade and conflict: Uncertainty, strategic signaling, and interstate disputes. Ann Arbor: University of Michigan Press.

[32] Yu, M., 2010. Trade, democracy, and the gravity equation. Journal of Development Economics 91 (2), 289-300.

[33] Yu, M., 2015. Processing trade, tariff reductions and firm productivity: Evidence from Chinese firms. The Economic Journal 125 (585), 943-988. 
Table 1 Import value percentage by ownership, category and mode

\begin{tabular}{lllll}
\hline & SOE & FIE & PIE & Total \\
\hline $\begin{array}{l}\text { Import value } \\
\text { percentage }\end{array}$ & $33.75 \%$ & $56.51 \%$ & $6.25 \%$ & \\
\hline
\end{tabular}

Panel A: BEC category

\begin{tabular}{lllll}
\hline Intermediate goods & $70.86 \%$ & $57.13 \%$ & $65.40 \%$ & $62.64 \%$ \\
Capital goods & $17.85 \%$ & $21.96 \%$ & $15.98 \%$ & $19.96 \%$ \\
Consumption goods & $3.01 \%$ & $3.26 \%$ & $6.19 \%$ & $3.36 \%$ \\
Others ${ }^{\text {a) }}$ & $8.28 \%$ & $17.64 \%$ & $12.43 \%$ & $14.03 \%$ \\
Total & $100 \%$ & $100 \%$ & $100 \%$ & $100 \%$ \\
\hline
\end{tabular}

Panel B: Ordinary and processing trade

\begin{tabular}{lllll}
\hline Ordinary & $72.69 \%$ & $25.15 \%$ & $67.04 \%$ & $44.95 \%$ \\
Processing & $27.31 \%$ & $74.85 \%$ & $32.96 \%$ & $55.05 \%$ \\
Total & $100 \%$ & $100 \%$ & $100 \%$ & $100 \%$ \\
\hline
\end{tabular}

Note: The import value is computed based on the China Customs Data for 2000-2006. It is deflated by the U.S. deflator and normalized by import growth.

a): "Others" represents the HS codes without corresponding BEC codes or the ownership type is not identified. 
Table 2 Descriptive statistics

\begin{tabular}{llllll}
\hline & Observations & Mean & Std. Dev. & Min & Max \\
\hline Conflict & $14,542,684$ & 0.003 & 0.009 & 0 & 0.087 \\
LnImport & $15,277,930$ & 8.355 & 2.881 & 0.065 & 22.957 \\
SOE & $15,277,930$ & 0.259 & 0.438 & 0 & 1 \\
FIE & $15,277,930$ & 0.595 & 0.491 & 0 & 1 \\
Imp_HHI & $15,277,930$ & 0.164 & 0.207 & 0.004 & 1 \\
Exchange & $13,079,534$ & 33.014 & 142.855 & 0.005 & 3135.410 \\
LnGDP & $13,075,466$ & 28.064 & 1.514 & 18.240 & 30.328 \\
LnPOP & $13,094,779$ & 17.997 & 1.451 & 9.846 & 20.994 \\
Intermediate goods & $14,686,204$ & 0.693 & 0.461 & 0 & 1 \\
Capital goods & $14,686,204$ & 0.204 & 0.403 & 0 & 1 \\
Consumption goods & $14,686,204$ & 0.101 & 0.301 & 0 & 1 \\
Ordinary goods & $15,277,930$ & 0.443 & 0.497 & 0 & 1 \\
\hline
\end{tabular}


Table 3 Impact of political conflict on Chinese imports

\begin{tabular}{lllllll}
\hline & $(1)$ & $(2)$ & $(3)$ & $(4)$ & $(5)$ & $(6)$ \\
\hline & \multicolumn{2}{c}{ Whole } & $\begin{array}{l}\text { US\&JPN } \\
\text { excluded }\end{array}$ & Conflict_other & Conflict_3 & Conflict_5 \\
\hline Conflict & $-0.822^{* * *}$ & $-0.906^{* * *}$ & $-0.664 *$ & $-1.854 * * *$ & $-1.175^{* * *}$ & $-1.257^{* * *}$ \\
& $(-2.767)$ & $(-2.629)$ & $(-1.682)$ & $(-3.005)$ & $(-3.537)$ & $(-3.658)$ \\
Conflict(t-1) & & -0.582 & -0.596 & $-1.970^{* * *}$ & $-2.217 * * *$ & $-2.326^{* * *}$ \\
& & $(-1.469)$ & $(-1.249)$ & $(-3.327)$ & $(-4.115)$ & $(-3.902)$ \\
Firm_year FE & $\mathrm{Y}$ & $\mathrm{Y}$ & $\mathrm{Y}$ & $\mathrm{Y}$ & $\mathrm{Y}$ & $\mathrm{Y}$ \\
HS6 FE & $\mathrm{Y}$ & $\mathrm{Y}$ & $\mathrm{Y}$ & $\mathrm{Y}$ & $\mathrm{Y}$ & $\mathrm{Y}$ \\
Country FE & $\mathrm{Y}$ & $\mathrm{Y}$ & $\mathrm{Y}$ & $\mathrm{Y}$ & $\mathrm{Y}$ & $\mathrm{Y}$ \\
Observations & 12226588 & 12226588 & 7623765 & 7706208 & 7706208 & 7706208 \\
Adj R2 & 0.373 & 0.373 & 0.403 & 0.390 & 0.390 & 0.390 \\
\hline
\end{tabular}

Note: The dependent variables are the natural logarithm of the import value. This table does not report the value for control variables Imp_HHI, Exchange, $L n G D P$, and $L n P O P$. We control for firm-year fixed effects, country fixed effects, and product in HS6 fixed effects in all columns. Imports from the U.S. and Japan are excluded in column 3-6. Robust standard errors are clustered at the country level and t statistics are reported in parentheses. $* * *, * *$, and $*$ represent the significance level at $0.01,0.05$, and 0.1 respectively. 
Table 4 Impact of conflicts by BEC categories

\begin{tabular}{lllllll}
\hline & $(1)$ & $(2)$ & $(3)$ & $(4)$ & $(5)$ & $(6)$ \\
\hline & \multicolumn{2}{l}{ Including U.S. and Japan } & & \multicolumn{2}{l}{ Excluding U.S. and Japan } & \\
& $\begin{array}{l}\text { Intermediate } \\
\text { goods }\end{array}$ & $\begin{array}{l}\text { Capital } \\
\text { goods }\end{array}$ & $\begin{array}{l}\text { Consumption } \\
\text { goods }\end{array}$ & $\begin{array}{l}\text { Intermediate } \\
\text { goods }\end{array}$ & $\begin{array}{l}\text { Capital } \\
\text { goods }\end{array}$ & $\begin{array}{l}\text { Consumption } \\
\text { goods }\end{array}$ \\
\hline Conflict & $-0.869^{* * *}$ & -0.372 & -0.160 & $-0.637^{*}$ & -0.669 & 0.606 \\
& $(-2.877)$ & $(-0.694)$ & $(-0.232)$ & $(-1.727)$ & $(-1.216)$ & $(1.177)$ \\
Conflict(t-1) & -0.571 & -0.497 & -0.893 & -0.624 & -0.515 & -0.935 \\
& $(-1.478)$ & $(-0.886)$ & $(-1.470)$ & $(-1.354)$ & $(-0.741)$ & $(-1.643)$ \\
Firm_year FE & $\mathrm{Y}$ & $\mathrm{Y}$ & $\mathrm{Y}$ & $\mathrm{Y}$ & $\mathrm{Y}$ & $\mathrm{Y}$ \\
HS6 FE & $\mathrm{Y}$ & $\mathrm{Y}$ & $\mathrm{Y}$ & $\mathrm{Y}$ & $\mathrm{Y}$ & $\mathrm{Y}$ \\
Country FE & $\mathrm{Y}$ & $\mathrm{Y}$ & $\mathrm{Y}$ & $\mathrm{Y}$ & $\mathrm{Y}$ & $\mathrm{Y}$ \\
Observations & 8109666 & 2296022 & 1159446 & 5080326 & 1276947 & 792592 \\
Adj R2 & 0.362 & 0.414 & 0.385 & 0.404 & 0.417 & 0.417
\end{tabular}

Note: The dependent variables are the natural logarithm of the import value. This table does not report the value for control variables Imp_HHI, Exchange, $L n G D P$, and $L n P O P$. We control for firm-year fixed effects, country fixed effects, and product in HS6 fixed effects in all columns. Robust standard errors are clustered at the country level and $t$ statistics are reported in parentheses. $* * *, * *$, and $*$ represent the significance level at $0.01,0.05$, and 0.1 respectively. For the conversion table between HS6 code to BEC categories and SITC groups, see website: https://unstats.un.org/unsd/trade/classifications/correspondence-tables.asp. 
Table 5 Impact of political conflicts by different ownership

\begin{tabular}{lllll}
\hline & $(1)$ & $(2)$ & $(3)$ & $(4)$ \\
\hline Conflict & Whole & U.S. and Japan excluded & U.S. excluded & Japan excluded \\
& -0.273 & 0.758 & -0.098 & 0.286 \\
Conflict $(t-1)$ & $(-0.304)$ & $(0.729)$ & $(-0.107)$ & $(0.272)$ \\
& -0.531 & -0.561 & -0.645 & -0.457 \\
Conflict*SOE & $(-1.362)$ & $(-1.196)$ & $(-1.617)$ & $(-0.993)$ \\
& $-2.500^{* * *}$ & $-2.650^{* * *}$ & $-2.146 * * *$ & $-2.924 * * *$ \\
Conflict*FIE & $(-4.359)$ & $(-3.712)$ & $(-3.718)$ & $(-4.626)$ \\
& 0.940 & -0.536 & 0.324 & 0.560 \\
Firm_year FE & $(0.722)$ & $(-0.369)$ & $(0.253)$ & $(0.343)$ \\
HS6 FE & $\mathrm{Y}$ & $\mathrm{Y}$ & $\mathrm{Y}$ & $\mathrm{Y}$ \\
Country FE & $\mathrm{Y}$ & $\mathrm{Y}$ & $\mathrm{Y}$ & $\mathrm{Y}$ \\
Observations & 12226588 & 7623765 & $\mathrm{Y}$ & $\mathrm{Y}$ \\
Adj R2 & 0.373 & 0.403 & 10650607 & 9198797 \\
\hline
\end{tabular}

Note: The dependent variables are the natural logarithm of the import value. This table does not report the value for control variables Imp_HHI, Exchange, LnGDP, and LnPOP. We control for firm-year fixed effects, country fixed effects, and product in HS6 fixed effects in all columns. Robust standard errors are clustered at the country level and $t$ statistics are reported in parentheses. ***,**, and * represent the significance level at $0.01,0.05$, and 0.1 respectively. 
Table 6 Impact of political conflicts for SOEs

\begin{tabular}{llllll}
\hline & $(1)$ & $(2)$ & $(3)$ & $(4)$ & $(5)$ \\
\hline & & \multicolumn{2}{c}{ Including U.S. and Japan } & \multicolumn{2}{c}{ Excluding U.S. and Japan } \\
\hline SOE & $\begin{array}{l}\text { SOE } \\
\text { Intermediate goods }\end{array}$ & $\begin{array}{l}\text { SOE } \\
\text { Capital goods }\end{array}$ & $\begin{array}{l}\text { SOE } \\
\text { Consumption goods }\end{array}$ & SOE \\
\hline & $-0.804^{* *}$ & $-1.000^{* * *}$ & -0.352 & 0.559 & -0.551 \\
Conflict $(t-1)$ & $-1.338^{* *}$ & $-1.478^{* *}$ & $(-0.499)$ & $(0.829)$ & $(-1.182)$ \\
& $(-2.238)$ & $(-2.485)$ & -1.262 & -1.175 & $-1.313^{* *}$ \\
Firm_year FE & $\mathrm{Y}$ & $\mathrm{Y}$ & $(-1.587)$ & $(-1.317)$ & $(-2.218)$ \\
HS6 FE & $\mathrm{Y}$ & $\mathrm{Y}$ & $\mathrm{Y}$ & $\mathrm{Y}$ & $\mathrm{Y}$ \\
Country FE & $\mathrm{Y}$ & $\mathrm{Y}$ & $\mathrm{Y}$ & $\mathrm{Y}$ & $\mathrm{Y}$ \\
Observations & 3420129 & 2182603 & $\mathrm{Y}$ & $\mathrm{Y}$ & $\mathrm{Y}$ \\
Adj R2 & 0.402 & 0.395 & 692432 & 417438 & 2290783 \\
\hline
\end{tabular}

Note: The dependent variables are the natural logarithm of the import value. This table does not report the value for control variables Imp_HHI, Exchange, $L n G D P$, and $L n P O P$. We control for firm-year fixed effects, country fixed effects, and product in HS6 fixed effects in all columns. Robust standard errors are clustered at the country level and $t$ statistics are reported in parentheses. $* * *, * *$, and $*$ represent the significance level at $0.01,0.05$, and 0.1 respectively. 
Table 7 Impact of political conflicts (industry-level) by using PPML

\begin{tabular}{lllll}
\hline & $(1)$ & $(2)$ & $(3)$ & $(4)$ \\
\hline Conflict & \multicolumn{1}{c}{ Whole } & -0.002 & U.S. \&JPN excluded \\
& -0.017 & $-0.308^{* *}$ & $(-0.053)$ & $-0.511^{* * *}$ \\
Conflict $(t-1)$ & $(-0.265)$ & $(-0.819)$ & $-0.062^{*}$ & $(-1.340)$ \\
& $-0.070^{*}$ & -0.036 & $(-1.678)$ & -0.024 \\
Conflict $*$ SOE & $(-1.156)$ & $(-0.618)$ & & $(-0.412)$ \\
& & $-0.584^{* * *}$ & & $-0.492^{* * *}$ \\
Conflict $*$ FIE & & $(-1.843)$ & & $(-1.471)$ \\
& & $0.888^{* *}$ & & $1.222^{* * *}$ \\
Year FE & $(2.066)$ & $\mathrm{Y}$ & $(3.075)$ \\
HS6 FE & $\mathrm{Y}$ & $\mathrm{Y}$ & $\mathrm{Y}$ & $\mathrm{Y}$ \\
Country FE & $\mathrm{Y}$ & $\mathrm{Y}$ & $\mathrm{Y}$ & $\mathrm{Y}$ \\
Observations & $\mathrm{Y}$ & $\mathrm{Y}$ & 527768 & $\mathrm{Y}$ \\
& 588576 & 286933 & & 239324
\end{tabular}

Note: The dependent variables are the natural logarithm of the import values. We use PPML to address the zero trade problem. This table does not report the value for control variables Imp_HHI, Exchange, LnGDP, and LnPOP. We control for year fixed effects, country fixed effects, and product in HS6 fixed effects in all columns. T statistics are based on robust standard errors and reported in parentheses. $* * *, * *$, and $*$ represent the significance level at $0.01,0.05$, and 0.1 respectively. 
Table 8 Impact of political conflicts on processing and ordinary firms

\begin{tabular}{lllll}
\hline & $(1)$ & $(2)$ & $(5)$ & $(6)$ \\
\hline & Ordinary & Whole & US\&JPN excluded & \\
\hline Conflict & $-1.577^{* *}$ & 0.076 & Ordinary & Process \\
& $(-2.477)$ & $(0.188)$ & $-1.255^{*}$ & 0.144 \\
Conflict(t-1) & $-1.186^{*}$ & 0.448 & $(-1.844)$ & $(0.394)$ \\
& $(-1.967)$ & $(1.180)$ & $-1.176^{*}$ & 0.378 \\
Firm_year FE & $\mathrm{Y}$ & $\mathrm{Y}$ & $(-1.714)$ & $(0.770)$ \\
HS6 FE & $\mathrm{Y}$ & $\mathrm{Y}$ & $\mathrm{Y}$ & $\mathrm{Y}$ \\
Country FE & $\mathrm{Y}$ & $\mathrm{Y}$ & $\mathrm{Y}$ & $\mathrm{Y}$ \\
Observations & 5846984 & 6311891 & $\mathrm{Y}$ & $\mathrm{Y}$ \\
Adj R2 & 0.420 & 0.398 & 3573224 & 3997098 \\
\hline
\end{tabular}

Note: The dependent variables are the natural logarithm of the import value. This table does not report the value for control variables Imp_HHI, Exchange, LnGDP, and $L n P O P$. We control for firm-year fixed effects, country fixed effects, and product in HS6 fixed effects in all columns. Robust standard errors are clustered at the country level and $t$ statistics are reported in parentheses. $* * *, * *$, and $*$ represent the significance level at $0.01,0.05$, and 0.1 respectively. 
Table 9 Impact of political conflicts by country

\begin{tabular}{lllll}
\hline & $(1)$ & $(2)$ & $(3)$ & $(4)$ \\
\hline Conflict & Democracy & & Non-Democracy & \\
& $-0.926^{* *}$ & -0.280 & -1.487 & 1.044 \\
Conflict $(t-1)$ & $(-2.608)$ & $(-0.321)$ & $(-0.576)$ & $(0.230)$ \\
& -0.574 & -0.522 & 1.406 & 1.312 \\
Conflict*SOE & $(-1.416)$ & $(-1.308)$ & $(0.735)$ & $(0.680)$ \\
& & $-2.475^{* * *}$ & & -6.140 \\
Conflict*FIE & & $(-4.317)$ & & $(-1.657)$ \\
& & 0.902 & & 5.915 \\
Firm_year FE & & $(0.706)$ & & $(0.584)$ \\
HS6 FE & $\mathrm{Y}$ & $\mathrm{Y}$ & $\mathrm{Y}$ & $\mathrm{Y}$ \\
Country FE & $\mathrm{Y}$ & $\mathrm{Y}$ & $\mathrm{Y}$ & $\mathrm{Y}$ \\
Observations & 11767266 & 11767266 & 413439 & 413439 \\
Adjusted R2 & 0.371 & 0.371 & 0.478 & 0.478 \\
\hline
\end{tabular}

Note: The dependent variables are the natural logarithm of the import values. This table does not report the value for control variables Imp_HHI, Exchange, $L n G D P$, and $L n P O P$. We control for firm-year fixed effects, country fixed effects, and product in HS6 fixed effects in all columns. Robust standard errors are clustered at the country level and $t$ statistics are reported in parentheses. ${ }^{* * *},{ }^{* *}$, and ${ }^{*}$ represent the significance level at $0.01,0.05$, and 0.1 respectively. 
Table 10 Instrumental variable test

\begin{tabular}{|c|c|c|c|c|c|}
\hline & $(1)$ & $(2)$ & (3) & (4) & $(5)$ \\
\hline & U.S \&Japan included & \multicolumn{4}{|c|}{ U.S \&Japan excluded } \\
\hline & Whole & Whole & Intermediate & ordinary & process \\
\hline \multirow{2}{*}{ Conflict } & $-3.886 * * *$ & $-4.384 * * *$ & $-3.302 * * *$ & $-5.100 * * *$ & $-3.378 * * *$ \\
\hline & $(-8.419)$ & $(-8.369)$ & $(-5.187)$ & $(-6.393)$ & $(-4.673)$ \\
\hline \multirow[t]{2}{*}{ Conflict $(t-1)$} & $-1.044 * * *$ & $-1.370^{* * *}$ & $-1.030 * * *$ & $-2.091 * * *$ & $-0.470 *$ \\
\hline & $(-7.024)$ & $(-8.440)$ & $(-5.081)$ & $(-9.332)$ & $(-1.953)$ \\
\hline Firm_year FE & $\mathrm{Y}$ & $\mathrm{Y}$ & $\mathrm{Y}$ & $\mathrm{Y}$ & $\mathrm{Y}$ \\
\hline HS6 FE & $\mathrm{Y}$ & $\mathrm{Y}$ & $\mathrm{Y}$ & $\mathrm{Y}$ & $\mathrm{Y}$ \\
\hline Country FE & $\mathrm{Y}$ & $\mathrm{Y}$ & $\mathrm{Y}$ & $\mathrm{Y}$ & $\mathrm{Y}$ \\
\hline Observations & 9853031 & 5741160 & 3732370 & 3054663 & 2640406 \\
\hline Adj R2 & 0.378 & 0.413 & 0.411 & 0.449 & 0.440 \\
\hline Anderson-Rubin Wald F test & 70.85 & 69.99 & 26.89 & 40.81 & 21.83 \\
\hline
\end{tabular}

Note: The dependent variables are the natural logarithm of the import values. $* * *, * *$, and $*$ represent the significance level at $0.01,0.05$, and 0.1 respectively. This table does not report the value for control variables Imp_HHI, Exchange, LnGDP, and LnPOP. We control for firm-year fixed effects, country fixed effects, and product in HS6 fixed effects in all columns. T statistics based on robust standard errors are reported in parentheses. 
Figure 1 Political conflicts: China vs. USA, China vs. Japan

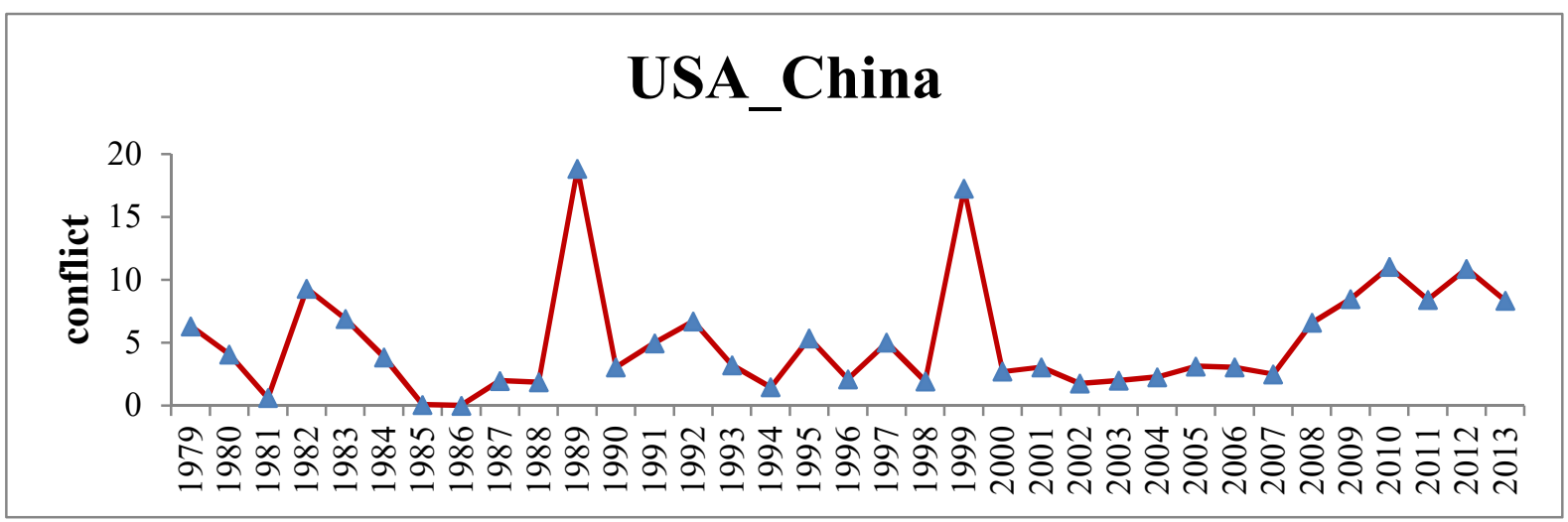

\section{China_Japan}

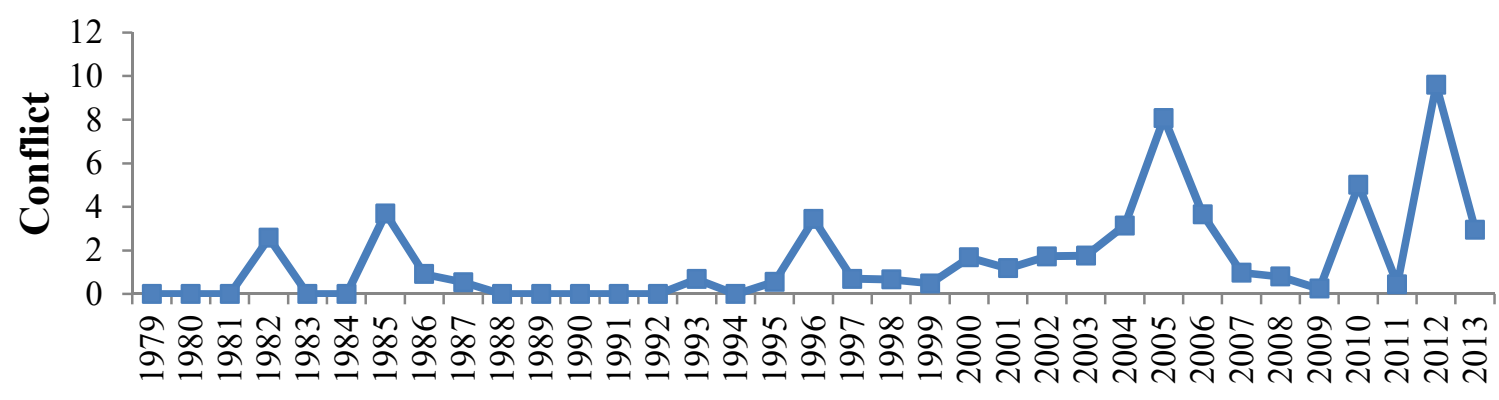

Source: Calculated by the authors based on data from GDELT. 


\section{Appendix}

Table A1 Different type initiating events

\begin{tabular}{ll}
\hline Agriculture & Amnesty International \\
Business & Civilian \\
Criminal & Development \\
Education & Elites \\
Environmental & Government \\
Greenpeace & Health \\
Human Rights & Insurgents \\
Inter-Governmental Organization & International Militarized Group \\
International/Transnational Generic & Judiciary \\
Labor & Legislature \\
Media & Military \\
Moderate & Multinational Corporation \\
Non-Governmental Movement & Non-Governmental Organization \\
Peacekeepers & Political Opposition \\
Radical & Rebels \\
Red Cross & Refugees \\
Separatist Rebels & Settler \\
State Intelligence & Unaligned Armed Forces \\
Unidentified State Actor & United Nations \\
\hline
\end{tabular}


Table A2 Description of conflict events

\begin{tabular}{lll}
\hline \multicolumn{2}{l}{ Panel A: Economic events } \\
$\begin{array}{l}\text { CAMEO event } \\
\text { code }\end{array}$ & Goldstein score & Event description \\
\hline 1011 & -5 & Demand economic cooperation \\
1031 & -5 & Demand economic aid \\
1054 & -5 & Demand easing of economic sanctions, boycott, or embargo \\
1244 & -4 & Refuse to ease economic sanctions, boycott, or embargo \\
127 & -5 & Reject plan, agreement to settle dispute \\
1312 & -5.8 & Threaten to boycott, embargo, or sanction \\
1621 & -5.6 & Reduce or stop economic assistance \\
163 & -8 & Impose embargo, boycott, or sanctions \\
\hline
\end{tabular}

Panel B: Non-economic events

\begin{tabular}{|c|c|c|}
\hline $\begin{array}{l}\text { CAMEO event } \\
\text { code }\end{array}$ & Goldstein score & Event description \\
\hline 11 & -0.1 & Decline comment \\
\hline 12 & -0.4 & Make pessimistic comment \\
\hline 16 & -2 & Deny responsibility \\
\hline 24 & -0.3 & Appeal for political reform, not specified below \\
\hline 241 & -0.3 & Appeal for change in leadership \\
\hline 242 & -0.3 & Appeal for policy change \\
\hline 243 & -0.3 & Appeal for rights \\
\hline 244 & -0.3 & Appeal for change in institutions, regime \\
\hline 25 & -0.3 & Appeal to yield \\
\hline 251 & -0.3 & Appeal for easing of administrative sanctions \\
\hline 252 & -0.3 & Appeal for easing of popular dissent \\
\hline 253 & -0.3 & Appeal for release of persons or property \\
\hline 254 & -0.3 & Appeal for easing of economic sanctions, boycott, or embargo \\
\hline 255 & -0.3 & Appeal for target to allow international involvement (non-mediation) \\
\hline 256 & -0.3 & Appeal for de-escalation of military engagement \\
\hline 9 & -2 & INVESTIGATE \\
\hline 90 & -2 & Investigate, not specified below \\
\hline 91 & -2 & Investigate crime, corruption \\
\hline 92 & -2 & Investigate human rights abuses \\
\hline 93 & -2 & Investigate military action \\
\hline 94 & -2 & Investigate war crimes \\
\hline 10 & -5 & DEMAND \\
\hline 100 & -5 & Demand, not specified below \\
\hline 101 & -5 & Demand information, investigation \\
\hline
\end{tabular}




\begin{tabular}{|c|c|c|}
\hline 1012 & -5 & Demand military cooperation \\
\hline 1013 & -5 & Demand judicial cooperation \\
\hline 1014 & -5 & Demand intelligence cooperation \\
\hline 102 & -5 & Demand policy support \\
\hline 103 & -5 & Demand aid, protection, or peacekeeping \\
\hline 1032 & -5 & Demand military aid \\
\hline 1033 & -5 & Demand humanitarian aid \\
\hline 1034 & -5 & Demand military protection or peacekeeping \\
\hline 104 & -5 & Demand political reform, not specified below \\
\hline 1041 & -5 & Demand change in leadership \\
\hline 1042 & -5 & Demand policy change \\
\hline 1043 & -5 & Demand rights \\
\hline 1044 & -5 & Demand change in institutions, regime \\
\hline 105 & -5 & Demand mediation \\
\hline 1051 & -5 & Demand easing of administrative sanctions \\
\hline 1052 & -5 & Demand easing of political dissent \\
\hline 1053 & -5 & Demand release of persons or property \\
\hline 1055 & -5 & Demand that target allows international involvement (non-mediation) \\
\hline 1056 & -5 & Demand de-escalation of military engagement \\
\hline 106 & -5 & Demand withdrawal \\
\hline 107 & -5 & Demand ceasefire \\
\hline 108 & -5 & Demand meeting, negotiation \\
\hline 11 & -2 & DISAPPROVE \\
\hline 110 & -2 & Disapprove, not specified below \\
\hline 111 & -2 & Criticize or denounce \\
\hline 112 & -2 & Accuse, not specified below \\
\hline 1121 & -2 & Accuse of crime, corruption \\
\hline 1122 & -2 & Accuse of human rights abuses \\
\hline 1123 & -2 & Accuse of aggression \\
\hline 1124 & -2 & Accuse of war crimes \\
\hline 1125 & -2 & Accuse of espionage, treason \\
\hline 113 & -2 & Rally opposition against \\
\hline 114 & -2 & Complain officially \\
\hline 115 & -2 & Bring lawsuit against \\
\hline 116 & -2 & Find guilty or liable (legally) \\
\hline 12 & -4 & REJECT \\
\hline 120 & -4 & Reject, not specified below \\
\hline 121 & -4 & Reject material cooperation \\
\hline 1211 & -4 & Reject economic cooperation \\
\hline
\end{tabular}




\begin{tabular}{|c|c|c|}
\hline 1212 & -4 & Reject military cooperation \\
\hline 122 & -4 & Reject request or demand for material aid, not specified below \\
\hline 1221 & -4 & Reject request for economic aid \\
\hline 1222 & -4 & Reject request for military aid \\
\hline 1223 & -4 & Reject request for humanitarian aid \\
\hline 1224 & -4 & Reject request for military protection or peacekeeping \\
\hline 123 & -4 & Reject request or demand for political reform, not specified below \\
\hline 1231 & -4 & Reject request for change in leadership \\
\hline 1232 & -4 & Reject request for policy change \\
\hline 1233 & -4 & Reject request for rights \\
\hline 1234 & -4 & Reject request for change in institutions, regime \\
\hline 124 & -4 & Refuse to yield, not specified below \\
\hline 1241 & -4 & Refuse to ease administrative sanctions \\
\hline 1242 & -4 & Refuse to ease popular dissent \\
\hline 1243 & -4 & Refuse to release persons or property \\
\hline 1245 & -4 & Refuse to allow international involvement (non mediation) \\
\hline 1246 & -4 & Refuse to de-escalate military engagement \\
\hline 125 & -5 & Reject proposal to meet, discuss, or negotiate \\
\hline 126 & -5 & Reject mediation \\
\hline 128 & -5 & Defy norms, law \\
\hline 129 & -5 & Veto \\
\hline 13 & -6 & THREATEN \\
\hline 130 & -4.4 & Threaten, not specified below \\
\hline 131 & -5.8 & Threaten non-force, not specified below \\
\hline 1311 & -5.8 & Threaten to reduce or stop aid \\
\hline 1313 & -5.8 & Threaten to reduce or break relations \\
\hline 132 & -5.8 & Threaten with administrative sanctions, not specified below \\
\hline 1321 & -5.8 & Threaten to impose restrictions on political freedoms \\
\hline 1322 & -5.8 & Threaten to ban political parties or politicians \\
\hline 1323 & -5.8 & Threaten to impose curfew \\
\hline 1324 & -5.8 & Threaten to impose state of emergency or martial law \\
\hline 133 & -5.8 & Threaten political dissent, protest \\
\hline 134 & -5.8 & Threaten to halt negotiations \\
\hline 135 & -5.8 & Threaten to halt mediation \\
\hline 136 & -7 & Threaten to halt international involvement (non-mediation) \\
\hline 137 & -7 & Threaten with violent repression \\
\hline 138 & -7 & Threaten to use military force, not specified below \\
\hline 1381 & -7 & Threaten blockade \\
\hline 1382 & -7 & Threaten occupation \\
\hline
\end{tabular}




\begin{tabular}{|c|c|c|}
\hline 1383 & -7 & Threaten unconventional violence \\
\hline 1384 & -7 & Threaten conventional attack \\
\hline 1385 & -7 & Threaten attack with WMD \\
\hline 139 & -7 & Give ultimatum \\
\hline 14 & -6.5 & PROTEST \\
\hline 140 & -6.5 & Engage in political dissent, not specified below \\
\hline 141 & -6.5 & Demonstrate or rally \\
\hline 1411 & -6.5 & Demonstrate for leadership change \\
\hline 1412 & -6.5 & Demonstrate for policy change \\
\hline 1413 & -6.5 & Demonstrate for rights \\
\hline 1414 & -6.5 & Demonstrate for change in institutions, regime \\
\hline 142 & -6.5 & Conduct hunger strike, not specified below \\
\hline 1421 & -6.5 & Conduct hunger strike for leadership change \\
\hline 1422 & -6.5 & Conduct hunger strike for policy change \\
\hline 1423 & -6.5 & Conduct hunger strike for rights \\
\hline 1424 & -6.5 & Conduct hunger strike for change in institutions, regime \\
\hline 143 & -6.5 & Conduct strike or boycott, not specified below \\
\hline 1431 & -6.5 & Conduct strike or boycott for leadership change \\
\hline 1432 & -6.5 & Conduct strike or boycott for policy change \\
\hline 1433 & -6.5 & Conduct strike or boycott for rights \\
\hline 1434 & -6.5 & Conduct strike or boycott for change in institutions, regime \\
\hline 144 & -7.5 & Obstruct passage, block \\
\hline 1441 & -7.5 & Obstruct passage to demand leadership change \\
\hline 1442 & -7.5 & Obstruct passage to demand policy change \\
\hline 1443 & -7.5 & Obstruct passage to demand rights \\
\hline 1444 & -7.5 & Obstruct passage to demand change in institutions, regime \\
\hline 145 & -7.5 & Protest violently, riot \\
\hline 1451 & -7.5 & Engage in violent protest for leadership change \\
\hline 1452 & -7.5 & Engage in violent protest for policy change \\
\hline 1453 & -7.5 & Engage in violent protest for rights \\
\hline 1454 & -7.5 & Engage in violent protest for change in institutions, regime \\
\hline 15 & -7.2 & EXHIBIT FORCE POSTURE \\
\hline 150 & -7.2 & Demonstrate military or police power, not specified below \\
\hline 151 & -7.2 & Increase police alert status \\
\hline 152 & -7.2 & Increase military alert status \\
\hline 153 & -7.2 & Mobilize or increase police power \\
\hline 154 & -7.2 & Mobilize or increase armed forces \\
\hline 16 & -4 & REDUCE RELATIONS \\
\hline 160 & -4 & Reduce relations, not specified below \\
\hline
\end{tabular}




\begin{tabular}{|c|c|c|}
\hline 161 & -4 & Reduce or break diplomatic relations \\
\hline 162 & -5.6 & Reduce or stop aid, not specified below \\
\hline 1622 & -5.6 & Reduce or stop military assistance \\
\hline 1623 & -5.6 & Reduce or stop humanitarian assistance \\
\hline 164 & -7 & Halt negotiations \\
\hline 165 & -6.5 & Halt mediation \\
\hline 166 & -7 & Expel or withdraw, not specified below \\
\hline 1661 & -7 & Expel or withdraw peacekeepers \\
\hline 1662 & -7 & Expel or withdraw inspectors, observers \\
\hline 1663 & -7 & Expel or withdraw aid agencies \\
\hline 17 & -7 & COERCE \\
\hline 170 & -7 & Coerce, not specified below \\
\hline 171 & -9.2 & Seize or damage property, not specified below \\
\hline 1711 & -9.2 & Confiscate property \\
\hline 1712 & -9.2 & Destroy property \\
\hline 172 & -5 & Impose administrative sanctions, not specified below \\
\hline 1721 & -5 & Impose restrictions on political freedoms \\
\hline 1722 & -5 & Ban political parties or politicians \\
\hline 1723 & -5 & Impose curfew \\
\hline 1724 & -5 & Impose state of emergency or martial law \\
\hline 173 & -5 & Arrest, detain, or charge with legal action \\
\hline 174 & -5 & Expel or deport individuals \\
\hline 175 & -9 & Use tactics of violent repression \\
\hline 18 & -9 & ASSAULT \\
\hline 180 & -9 & Use unconventional violence, not specified below \\
\hline 181 & -9 & Abduct, hijack, or take hostage \\
\hline 182 & -9.5 & Physically assault, not specified below \\
\hline 1821 & -9 & Sexually assault \\
\hline 1822 & -9 & Torture \\
\hline 1823 & -10 & Kill by physical assault \\
\hline 183 & -10 & Conduct suicide, car, or other non-military bombing, not spec below \\
\hline 1831 & -10 & Carry out suicide bombing \\
\hline 1832 & -10 & Carry out car bombing \\
\hline 1833 & -10 & Carry out roadside bombing \\
\hline 184 & -8 & Use as human shield \\
\hline 185 & -8 & Attempt to assassinate \\
\hline 186 & -10 & Assassinate \\
\hline 19 & -10 & FIGHT \\
\hline 190 & -10 & Use conventional military force, not specified below \\
\hline
\end{tabular}




\begin{tabular}{lll}
191 & -9.5 & Impose blockade, restrict movement \\
192 & -9.5 & Occupy territory \\
193 & -10 & Fight with small arms and light weapons \\
194 & -10 & Fight with artillery and tanks \\
195 & -10 & Employ aerial weapons \\
196 & -9.5 & Violate ceasefire \\
20 & -10 & USE UNCONVENTIONAL MASS VIOLENCE \\
200 & -10 & Use unconventional mass violence, not specified below \\
201 & -9.5 & Engage in mass expulsion \\
202 & -10 & Engage in mass killings \\
203 & -10 & Engage in ethnic cleansing \\
204 & -10 & Use weapons of mass destruction, not specified below \\
2041 & -10 & Use chemical, biological, or radiological weapons \\
2042 & -10 & Detonate nuclear weapons \\
\hline
\end{tabular}

Note: CAMEO (Conflict and Mediation Event Observations). 
Table A3 Conflict events (Goldstein score<=-9) between China and other countries

\begin{tabular}{|c|c|c|c|c|}
\hline Actor country & Target country & quarter & Global event id & Goldstein score \\
\hline $\mathrm{CHN}$ & USA & $2005 q 4$ & 57782669 & -9 \\
\hline $\mathrm{CHN}$ & USA & $2005 q 4$ & 57782670 & -9 \\
\hline USA & $\mathrm{CHN}$ & $2004 q 1$ & 50633911 & -10 \\
\hline USA & $\mathrm{CHN}$ & $2006 q 3$ & 179816118 & -9.5 \\
\hline USA & $\mathrm{CHN}$ & $2006 \mathrm{q} 3$ & 179816119 & -9.5 \\
\hline $\mathrm{CHN}$ & JPN & $2003 q 4$ & 49259261 & -9.5 \\
\hline $\mathrm{CHN}$ & JPN & $2003 q 4$ & 49259260 & -9.5 \\
\hline $\mathrm{CHN}$ & JPN & $2005 q 2$ & 55735206 & -9.5 \\
\hline $\mathrm{CHN}$ & JPN & $2006 q 3$ & 179193830 & -9.5 \\
\hline JPN & $\mathrm{CHN}$ & $2005 q 2$ & 55830156 & -9.5 \\
\hline JPN & $\mathrm{CHN}$ & $2005 q 2$ & 55748243 & -9.5 \\
\hline JPN & $\mathrm{CHN}$ & $2005 q 2$ & 55830157 & -9.5 \\
\hline GBR & $\mathrm{CHN}$ & $2001 q 3$ & 38656006 & -10 \\
\hline GBR & $\mathrm{CHN}$ & $2004 q 3$ & 53587873 & -10 \\
\hline GBR & $\mathrm{CHN}$ & $2004 q 3$ & 53587874 & -10 \\
\hline KGZ & $\mathrm{CHN}$ & $2002 q 2$ & 42217857 & -10 \\
\hline KGZ & $\mathrm{CHN}$ & $2002 q 2$ & 42217856 & -10 \\
\hline KGZ & $\mathrm{CHN}$ & $2002 q 3$ & 42276352 & -10 \\
\hline KGZ & $\mathrm{CHN}$ & $2002 q 3$ & 42276353 & -10 \\
\hline KGZ & $\mathrm{CHN}$ & $2002 q 3$ & 42276351 & -10 \\
\hline KGZ & $\mathrm{CHN}$ & $2002 q 3$ & 42229175 & -10 \\
\hline KGZ & $\mathrm{CHN}$ & $2002 q 3$ & 42276354 & -10 \\
\hline KGZ & $\mathrm{CHN}$ & $2002 q 3$ & 42229176 & -10 \\
\hline $\mathrm{CHN}$ & SYR & $2006 q 3$ & 179822529 & -9.5 \\
\hline $\mathrm{CHN}$ & SYR & $2006 \mathrm{q} 3$ & 179795965 & -10 \\
\hline SYR & $\mathrm{CHN}$ & $2006 q 3$ & 179812840 & -9.5 \\
\hline SYR & $\mathrm{CHN}$ & $2006 q 3$ & 179812841 & -9.5 \\
\hline $\mathrm{CAN}$ & $\mathrm{CHN}$ & $2004 q 3$ & 53737544 & -9.2 \\
\hline $\mathrm{CHN}$ & CAN & $2004 q 3$ & 53725209 & -9.5 \\
\hline PAK & $\mathrm{CHN}$ & $2005 q 2$ & 55705280 & -10 \\
\hline $\mathrm{CHN}$ & PAK & $2001 q 4$ & 39482681 & -10 \\
\hline $\mathrm{CHN}$ & RUS & $2005 q 3$ & 57057742 & -9 \\
\hline RUS & $\mathrm{CHN}$ & $2005 q 3$ & 57063577 & -9 \\
\hline $\mathrm{CHN}$ & PHL & $2001 q 2$ & 36396603 & -9 \\
\hline $\mathrm{CHN}$ & PHL & $2001 \mathrm{q} 3$ & 38321438 & -9 \\
\hline $\mathrm{CHN}$ & PHL & $2001 \mathrm{q} 3$ & 38321439 & -9 \\
\hline NOR & $\mathrm{CHN}$ & $2000 q 4$ & 35065779 & -10 \\
\hline
\end{tabular}




\begin{tabular}{lllll} 
IRQ & CHN & $2003 \mathrm{q} 1$ & 45920128 & -10 \\
AFG & CHN & $2004 \mathrm{q} 3$ & 53043990 & -10 \\
CHN & KOR & $2004 \mathrm{q} 3$ & 53515418 & -9.5 \\
IND & CHN & $2000 \mathrm{q} 4$ & 34212884 & -9.5 \\
ISR & CHN & $2003 \mathrm{q} 1$ & 44632740 & -9.5 \\
VUT & CHN & $2004 \mathrm{q} 4$ & 54477988 & -9 \\
VUT & CHN & $2004 \mathrm{q} 4$ & 54477987 & -9 \\
\hline
\end{tabular}


Table A4 First stage results of 2SLS regression

\begin{tabular}{llllll}
\hline & $(1)$ & $(2)$ & $(3)$ & $(4)$ & $(5)$ \\
\hline & $\begin{array}{l}\text { U.S \&Japan } \\
\text { included }\end{array}$ & \multicolumn{2}{l}{ U.S \&Japan excluded } & & \\
\hline Whole & Whole & Intermediate & Ordinary & Process \\
\hline IV & $10.798^{* * *}$ & $10.891 * * *$ & $11.153 * * *$ & $9.669 * * *$ & $11.748^{* * *}$ \\
& $(402.72)$ & $(317.85)$ & $(269.49)$ & $(204.01)$ & $(238.30)$ \\
Conflict(t-1) & $-0.208^{* * *}$ & $-0.184 * * *$ & $-0.191 * * *$ & $-0.166^{* * *}$ & $-0.205^{* * *}$ \\
& $(-393.45)$ & $(-314.88)$ & $(-264.32)$ & $(-198.62)$ & $(-239.95)$ \\
Firm_year FE & $\mathrm{Y}$ & $\mathrm{Y}$ & $\mathrm{Y}$ & $\mathrm{Y}$ & $\mathrm{Y}$ \\
HS6 FE & $\mathrm{Y}$ & $\mathrm{Y}$ & $\mathrm{Y}$ & $\mathrm{Y}$ & $\mathrm{Y}$ \\
Country FE & $\mathrm{Y}$ & $\mathrm{Y}$ & $\mathrm{Y}$ & $\mathrm{Y}$ & $\mathrm{Y}$ \\
Observations & 9853031 & 5741160 & 3732370 & 3054663 & 2640406 \\
\hline
\end{tabular}

Note: The dependent variables are the natural logarithm of the import values. ${ }^{* * *},{ }^{* *}$, and $*$ represent the significance level at $0.01,0.05$, and 0.1 respectively. This table does not report the value for control variables Imp_HHI, Exchange, LnGDP, and LnPOP. We control for firm-year fixed effects, country fixed effects, and product (HS6) fixed effects in all columns. T statistics based on robust standard errors are reported in parentheses. 